\title{
Country of Origin Effect in a Lithuanian Market of Vitamins and Dietary Supplements
}

\author{
Ingrida Smaiziene $^{1} \&$ Rimgaile Vaitkiene ${ }^{1}$ \\ ${ }^{1}$ Kaunas University of Technology, Lithuania \\ Correspondence: Ingrida Smaiziene, Kaunas University of Technology, K. Donelaiciost. 20, LT-44239 Kaunas, \\ Lithuania. Tel: 370-37-300122. E-mail: ingrida.smaiziene@ktu.lt
}

Received: September 5, 2013

Accepted: October 9, 2013

Online Published: November 22, 2013

doi: 10.5539/ibr.v6n12p118

URL: http://dx.doi.org/10.5539/ibr.v6n12p118

\begin{abstract}
The country of origin (COO) - as an extrinsic cue of a product - influences consumer's perception of a product and his/her purchase decisions. The $\mathrm{COO}$ effect manifests in a different way in various geographical, differently developed economics and different products' markets. The article analyses the problem how the COO effect manifests in the Lithuanian market of vitamins dietary supplements.

This study aims to disclose consumers' perceptions on vitamins and dietary supplements produced in sixteen countries and highlight the importance of the $\mathrm{COO}$ in decision-making when purchasing vitamins and dietary supplements. The research method applied is consumer survey. The consumers' opinion about the quality, price and safety of vitamins and dietary supplements produced in Lithuania and fifteen foreign countries have been surveyed. The importance of the $\mathrm{COO}$ when making a purchase decision in the market of vitamins and dietary supplements is disclosed.

The study results indicate that the product's $\mathrm{COO}$ is the factor of moderate importance in the product group researched. The vitamins and dietary supplements produced in developed economies are perceived as the ones of the best quality and most secure to use. The quality and safety of the vitamins and dietary products produced in China, the Ukraine, Poland and India have been rated the worst. The quality, prices and safety of the vitamins and dietary supplements produced in Lithuania are perceived similarly as the quality and safety of the preparations produced in developed countries and higher than the quality and safety of the preparations produced in neighboring countries.
\end{abstract}

Keywords: country of origin, country of origin effect, product perception, consumer behaviour, dietary supplements, Lithuania

\section{Introduction}

A product's country-of-origin ( $\mathrm{COO}$ ) effect refers to the consumers' perceptions, attitudes and behaviour towards the country of a product's production (Schweiger et al., 1997; Ghazali et al., 2008; Urbonavicius et al., 2011). Despite some emerging skeptical attitudes towards the relevance of a product's country-of-origin in global markets (Usunier, 2006), the COO effect remains a significant issue in the international business and marketing research (Tseng \& Balabanis, 2011; Wang et al., 2012; Samli, 2013). The necessity to cognize consumers' perceptions and attitudes towards the domestic and imported products increases both for national and global companies as both types of companies operate in highly competitive markets of local and foreign-made products (Ghazali et al., 2008; Ahmed \& d'Astous, 2008).

Verbal or visual symbols of $\mathrm{COO}$, integrated into a labelling, packaging, and advertising, serve for better identification and differentiation of the products (Ittersuma et al., 2003; Insch \& Florek, 2009). Thus, COO can be used as an important element of branding strategy, once sending a cue about a product's COO can make a significant influence on consumer perceptions of a brand (Phau \& Suntornnond, 2006; Clemens \& Babcock, 2004), and purchase intentions.

The findings of previous researches indicate that $\mathrm{COO}$ effect on consumers' perceptions and purchasing decisions are regional-specific and differ in emerging economies, when compared to the $\mathrm{COO}$ effect in the developed countries (Kaynak et al., 2000). Despite the COO researches in developing markets of Asia, particularly in China, increase in number, the researches on the expression of $\mathrm{COO}$ effect in Central and Eastern 
European markets have not been performed and published a lot yet.

It should be noted that the researches on the perceptions of post-soviet countries' consumers about the products produced in former Soviet countries, which are related in common history, are missing. The researches on friendliness and animosity of post-Soviet countries' consumers in respect of Soviet countries as well as researches on the influence of such attitudes upon consumer's behaviour are also missing.

The Lithuanian market has been chosen for this research because it can be treated as an example of the developing economy of Eastern Europe and post-soviet country. It is unclear how the general theoretical attitudes, which define the expression of $\mathrm{COO}$ effect, reflect situations in emerging and post-Soviet markets. Urbonavicius and Gineikiene's (2009) and Mockaitis et al. (2013) empirical findings suggest that COO effect in Lithuanian market just partly confirms findings of previous research carried in foreign countries.

Variety of $\mathrm{COO}$ effects across product categories indicates that the $\mathrm{COO}$ effect is not only regional-specific, but also product-specific phenomenon (Chattalas et al., 2008; Tseng \& Balabanis, 2011; Drozdenko \& Jensen, 2009; Insch \& Florek, 2009). The findings of Drozdenko and Jensen (2009) study show that consumers are more sensitive to $\mathrm{COO}$ of the products that are consumed directly (like energy drinks and toothpaste) compared to the products with less physical risk (shoes, cell phones, shirts, mp3 players). For frequently purchased necessity goods, consumers are expected to pay more attention to brands and prices than to COO (Insch \& Florek, 2009).

In this research, the product-specific approach has been chosen as well. Consumers' perceptions and behavioral intentions towards the foreign-made and domestic products have been explored in the Lithuanian market of vitamins and dietary supplements.

Euromonitor International Report on the market of vitamins and dietary supplements in Lithuania (April 2013) indicates that Lithuanian manufacturers of vitamins and dietary supplements compete successfully with foreign companies in the Lithuanian market. As Euromonitor International Report (2013) suggests, local companies have strong positions in the market place and are aggressive when it comes to offering lower prices. International companies are focused more on brand building and are expected to be a step ahead after the economic downturn, once consumers become less price-sensitive (Euromonitor International).

This study aims to disclose consumers' perceptions on vitamins and dietary supplements produced in different countries by highlighting the importance of the country of origin in decision-making when purchasing vitamins and dietary supplements. The research method applied is consumer survey.

The paper has been structured as follows. In the first part of the paper, theoretical insights to the country of origin effect are discussed. In the second part, the research methodology is presented. The study main findings are presented in the third part of the paper. The study results are discussed and hypotheses are tested in the fourth part of the paper.

\section{Theoretical Background and Research Hypotheses}

\subsection{Country of Origin as a Trigger of Consumers' Perceptions of a Product Attributes}

In the marketing literature, a product is treated as a collection of intrinsic and extrinsic information cues (Magnusson et al., 2011). Both internal and external cues are determinants of consumers' perceptions and attitudes towards the products, as well as determinants of purchasing intentions and decisions. Intrinsic attributes cannot be changed without changing the nature of the product itself (Profeta, 2008). Thus, intrinsic cues refer to such product attributes as material, color, taste, design, technical specification, nutritive and other physical specifications (Bloemer et al., 2009; Magnusson et al., 2011).

Extrinsic attributes are product attributes that are not part of the product itself (Profeta, 2008), but are related to the product. Thus, extrinsic cues refer to a product's price, warranty, brand name, logotype, slogan, store reputation, advertising, warranty, packaging, etc. (Bloemer et al., 2009). A product's country of origin (COO) is also considered as one the extrinsic cues that can trigger positive or negative consumers' perceptions and attitudes towards a product, as well as product selection and purchasing intentions (Agrawal \& Kamakura, 1999; Kayanak et al., 2000; Verlegh et al., 2005; Phau \& Suntornnond, 2006; Insch \& Florek, 2009).

Previous studies on the $\mathrm{COO}$ effect focus on a product's quality perceptions mostly. $\mathrm{COO}$ is considered as a signal of information that is used by consumers for predicting quality of a product (Hong \& Kang, 2006; Insch \& Florek, 2009; Chu et al., 2010; Sanyal \& Datta, 2011; Wang et al., 2012). COO plays a significant role of missing information, when consumers cannot determine a product's quality directly. In such cases, beliefs related to COO fill the gap of missing information about a product's quality (Sanyal \& Datta, 2011). This is extremely important in the market of vitamins and dietary supplements, where consumers have limited knowledge and 
abilities to evaluate quality of the nutritional supplements. It is possible to make the premise that in such a case when consumers lack intrinsic cues (or do not have enough competence to judge intrinsic attributes of a product), they pay more attention to extrinsic cues, and $\mathrm{COO}$ including.

Furthermore, we argue that $\mathrm{COO}$ determines not only perceptions of overall product quality, but it can also trigger consumers' perceptions and attitudes towards a product's other attributes, like price, safety, prestige, etc.

In some markets, the products produced in emerging economics might be perceived as cheaper ones, when comparing to products made in leading economics. Recent worldwide information about product safety problems in some countries may also result in the images of countries that fail in product safety assurance. In the market of dietary supplements, a product's $\mathrm{COO}$ can be a hint about costliness and safety of vitamins and dietary supplements.

Based on the above premise, it can be hypothesized that:

H1. When a consumer makes the decision to purchase vitamins and dietary supplements, $\mathrm{COO}$ is more important factor than a brand name.

\subsection{Determinants of the COO Effect}

$\mathrm{COO}$ effect in a market depends on a number of factors: product category (as discussed above), exogenous factors, and demographic and psychological characteristics (Phau \& Suntornnond, 2006).

\subsubsection{Exogenous Factors as the Determinants of COO Effect}

The findings of previous researches indicate that country-specific beliefs depend on number of exogenous antecedents. The level of economic development and closeness of the $\mathrm{COO}$ of a product are considered as the most important exogenous factors influencing $\mathrm{COO}$ effect in a market.

In many cases the approach that consumers have more favourable attitudes towards the products produced in the developed economics (Zhang, 1996; Mockaitis et al., 2013) is considered. This statement is supported by the number of empirical findings. As Jeong et al. (2012) claim, Chinese consumers are more confident and favourable about the quality and safety of the products from the United States. The COO research carried by Mockaitis et al. (2013) indicate that consumers in the emerging economics of Lithuania also rate products from developed economics of Western Europe, USA and Japan as the ones with the highest quality. Thus, in less developed economics consumers (especially the ones with higher education and high income) prefer products manufactured in the developed economics to local ones. In the developed economics, consumers have more positive perceptions and preferences for products produced in their own or the same level economics (Rezvani et al., 2012).

Geographical and cultural closeness of the product's country-of-origin is considered as another exogenous antecedent influencing consumers' perceptions of COO. It is considered that consumers have positive attitudes towards the products that are imported from the neighboring countries. Yet, the findings of the COO research in the Lithuanian market indicate that Lithuanian consumers do not hold favourable attitudes towards the products imported from the closest neighbors-Latvia, Estonia, Poland and Russia (Mockaitis et al., 2013).

Thus, it can be hypothesized that:

$\boldsymbol{H 2 a}$. Vitamins and dietary supplements produced in the developed economies are perceived as the ones with the best quality, safe and most expensive ones.

H2b. Vitamins and dietary supplements produced in emerging and developing economies are perceived as the ones with the lower quality, cheap and not safe.

\subsubsection{Psychological Factors as the Determinants of COO Effect}

Animosity and ethnocentrism are considered as psychological antecedents influencing the expression of COO effect in the markets as animosity and ethnocentrism can be sources of negative attitudes towards foreign products (Nijssen \& Douglas, 2004). Negative perceptions and hostile attitudes towards the particular COO of a product might be an outcome of historical, political, social or economic tension between the countries (Verlegh, 2007). Country-specific antipathy related to historical or ongoing events is defined as animosity (Li et al., 2012), and it makes the impact on consumers' behavioral decisions and actions (Russell \& Russell, 2006).

The results of the research by Urbonavicius and Gineikiene (2009) show that the above-mentioned theoretical attitudes about coherences of country-specific animosity and purchasing decisions only partly reflect the situation in the Lithuanian market. The empirical data collected by these researchers shows that Lithuanian consumers buy many products from the countries perceived with hostility. 
Level of ethnocentrism is considered as another important factor moderating the $\mathrm{COO}$ effect in the market. Ethnocentric consumers prefer domestic products as they believe that buying foreign products is morally wrong. Previous studies suggest that consumers high in ethnocentrism pay more attention to the country-of-origin cue (Chattalas et al., 2008), rate domestic products better, and wish to pay premium prices for domestic products (Drozdenko \& Jensen, 2009). The attitude that the level of ethnocentrism as well as animosity in different demographic groups of consumers differs is considered.

Based on the above premises, we hypothesize that:

H3. Lithuanian consumers rate Lithuanian vitamins and dietary supplements similarly as the vitamins and supplements produced in the neighboring countries-Russia, Poland, but worse than the supplements produced in developed economies.

\subsubsection{Demographic Variables as the Determinants of COO Effect}

The previous researches suggest that $\mathrm{COO}$ effects vary in the consumer groups with the different socio-demographic and socio-economic characteristics. Consumers' gender, age, education and income are the important endogenous antecedents that effect country-specific beliefs (Ahmed \& d'Astous, 2008; Profeta, 2008).

The most general presumption presented in the literature explores that females' perceptions of foreign products are more favourable than males (Josiassen \& Assaf, 2010). It is considered that people with high level of education attach less importance to product origin (Schweiger et al., 1997) and have more favourable perceptions of foreign products (Profeta, 2008).

The premise that younger customers rate foreign products more favorably than older ones (Josiassen \& Assaf, 2010 ) is made. Older consumers have more information about the origin of products, are more sensible about $\mathrm{COO}$ and have a higher preference for the products produced in the local or close markets (Profeta, 2008).

The previous studies also suggest a positive correlation between the consumers' income and favourable attitude towards the foreign products exists (Profeta, 2008).

Based on the above statements, we propose the following:

$\boldsymbol{H} 4 \boldsymbol{a}$. Consumers with lower level of education have more favourable perceptions of Lithuanian vitamins and dietary supplements.

H4b. Older consumers have more favourable perception of vitamins and dietary supplements produced in Lithuania and neighboring countries.

H4c. Consumers with low income have more favourable perception of vitamins and dietary supplements produced in Lithuania and neighboring countries.

\section{Methodology}

\subsection{Sampling and Data Collection}

The survey took place in Lithuania in April 2013. The mixed survey methods were used: coordinated survey online and survey-in-written.

A total of 398 filled-in questionnaires were received. For further analysis the 352 questionnaires, in which the respondents indicated that they bought dietary supplements in two latter years, were selected. The answers of the respondents who did not buy dietary supplements in two latter years were not included into the analysis. The sample consists of 352 consumers in Lithuania market, who are older than 18 years who purchase vitamins and dietary supplements.

The socio-demographic characteristics of the respondents are presented in Table 1. The respondents from large cities of Lithuania make 61.5 percent, from towns -27.2 percent, from small towns and villages - respectively 5.7 percent each. Females make the larger part of the respondents (87.5\%). This reveals the characteristics of the market of pharmaceutical products' consumers in Lithuania; in the market of the Republic of Lithuania women make $74 \%$ of purchasers of pharmaceutical preparations (Pharmacy shopper study Baltics 2012, AC Nielsen), and, as it is supposed, their larger part purchase vitamins and dietary supplements.

\subsection{Measures}

During the research, the consumers' opinion about dietary supplements from Lithuania and fifteen foreign countries has been surveyed. The countries have been selected by referring to the statistical data collected during the pilot research on the dietary supplements imported to the Lithuanian market and the content analysis of consumers' opinions in social websites. When applying the latter method, the discussions of consumers about dietary supplements purchased in foreign e-shops have been reviewed and most often mentioned countries, from 
which consumers send supplements hoping for better value for money, have been identified. These countries are the USA and Great Britain.

Table 1. Sample profile $(\mathrm{N}=352)$

\begin{tabular}{|c|c|c|c|}
\hline \multicolumn{2}{|c|}{ Socio-demographic and socio-economic characteristics } & \multirow[t]{2}{*}{ Frequency } & \multirow[t]{2}{*}{ Percentage } \\
\hline Gender: & & & \\
\hline & Female & 308 & 87.5 \\
\hline & Male & 44 & 12.5 \\
\hline \multicolumn{4}{|l|}{ Age: } \\
\hline & Up to 20 years. & 15 & 4.3 \\
\hline & $20-29$ years & 122 & 34.7 \\
\hline & $30-39$ years & 93 & 26.4 \\
\hline & $40-49$ years & 70 & 19.9 \\
\hline & $50-59$ years & 39 & 11.1 \\
\hline & 60 years and more & 13 & 3,7 \\
\hline \multicolumn{4}{|l|}{ Education: } \\
\hline & Basic & 5 & 1.4 \\
\hline & Secondary & 56 & 15.9 \\
\hline & Vocational & 10 & 2.8 \\
\hline & College & 43 & 12.2 \\
\hline & Higher & 238 & 67.6 \\
\hline \multicolumn{4}{|c|}{ Monthly income per } \\
\hline \multirow[t]{7}{*}{ household, Lt: } & Up to 1000 & 34 & 9.7 \\
\hline & $1001-2000$ & 73 & 20.7 \\
\hline & $2001-3000$ & 85 & 24.1 \\
\hline & $3001-4000$ & 62 & 17.6 \\
\hline & $4001-5000$ & 47 & 13.4 \\
\hline & More than 5000 & 47 & 13.4 \\
\hline & No answer & 4 & 1.1 \\
\hline
\end{tabular}

Despite the discussions occurring in the Internet environment that most supplements for the USA market are produced in China, in the surveyed social networks the strong standpoint that the supplements from the USA are of better quality or the proportion of the quality and price of such 'American' supplements is more acceptable prevails. Russia has been included into the list of surveyed countries due to the situation in the Lithuanian market when the pharmaceutical products produced in Russia are sold in marketing places because some part of them does not meet the requirements formulated in legal regulations and they are not sold in Lithuanian drugstores.

Five scales have been used to survey consumers' opinion. The first ten-point scale is aimed to determine the importance of different factors when a consumer makes decisions to purchase vitamins and dietary supplements (1-absolutely unimportant, 10 -very important). The data collected by means of this scale enables disclosing the importance of product's country of origin for the consumer in comparison to other factors influencing decisions of purchasing. The calculated Cronbach alpha coefficient shows high reliability of this scale (0.842).

In order to survey consumers' perceptions about the quality and price of dietary supplements produced in different countries, seven-point scales were used (respectively 1-very low quality, 7-very high quality; 1-very low price, 7-very high price). According to the Cronbach alpha coefficients, the reliability of these scales is 0.923 and 0.962 . 
The fourth scale was used to identify respondents' perceptions about safety of dietary supplements produced in Lithuania and foreign countries (1-not safe to use a product, 2-doubt about a product safety, 3 confident about a product safety). Referring to the Cronbach alpha coefficient, the reliability of this applied scale is 0.858 .

The additional scale with statements was used to collect additional data about respondents' perceptions about vitamins and dietary supplements produced in economics of different development level. The coefficient of the scale reliability according to Cronbach alpha is 0.729 .

The software SPSS 17.0 for Windows was used for the statistical data analysis. During the research the statistical level of significance 0.05 was chosen.

\section{Research Findings and Hypotheses Testing}

\subsection{COO as the Factor Influencing Decisions to Purchase Vitamins and Dietary Supplements}

Referring to the study results (Table 2), the named factors are divided into four groups according to the importance when a consumer chooses what vitamins and dietary supplements to purchase.

The most important factors in the respondents' choice of dietary supplements are as follows: personally tried quality (displays the highest mean score for all factors with a value of 9.14) and naturalness of the product (8.39). The analysis of correlation among the above-mentioned factors and consumers' demographic variables shows the statistically reliable positive link between the above-mentioned two attributes (personally tried product and naturalness) and respondents' education. The data presented in Table 2 show that the importance of these two attributes grows when the respondents' education increases $(\mathrm{r}=0.167 ; \mathrm{r}=0.148)$.

The following factors are attributed to the group of the important factors when making decisions to purchase dietary supplements - price (mean 7.97), expiry date (7.84), ecology (7.77), doctor's recommendations (7.59), discounts (7.54), the number and variety of vitamins and supplements in the composition (7.20), large amount of the active substance of interest $(7,14)$.

The statistically reliable positive correlation has been identified between the importance of supplements' expiry date and respondents' age $(\mathrm{r}=0.231)$ as well as the importance of supplements' ecology and respondents' age $(\mathrm{r}=0.131)$. The statistically reliable negative relation - between the number and variety of vitamins and supplements in the composition and respondents' age $(\mathrm{r}=-0.111)$.

The statistically positive correlation has been identified between the large amount of active substance of interest and respondents' education $(r=0,119)$. Statistically significant negative relations have been identified between the importance of price and respondents' income $(\mathrm{r}=-0.214)$, the importance of supplements' expiry date and respondents' income $(\mathrm{r}=-0.114)$ as well as the importance of offered discounts and respondents' income $(\mathrm{r}=-0.146)$.

The following factors are moderately important for the respondents in making decisions to purchase dietary supplements: large amount for reasonable price (6.52), recommendations of friends and acquaintances (6.49), recommendation of pharmacist (6.33), country of origin (6.16), known brand (6.14), how many times per day it is necessary to use (6.09), how many capsules per day it is necessary to take (6.06), consumers' comments in the Internet (5.38).

Table 2. The importance of the factors when a consumer makes decisions to purchase vitamins and dietary supplements

\begin{tabular}{|c|c|c|c|c|c|c|c|}
\hline \multirow{2}{*}{$\begin{array}{l}\text { Factors influencing purchase } \\
\text { intentions }\end{array}$} & \multirow{2}{*}{ Mean* } & \multicolumn{2}{|c|}{ Age } & \multicolumn{2}{|c|}{ Education } & \multicolumn{2}{|c|}{ Income } \\
\hline & & $\begin{array}{l}\text { Correlation } \\
\text { coefficient }\end{array}$ & $\begin{array}{c}\text { Sig. } \\
\text { (2-tailed) }\end{array}$ & $\begin{array}{l}\text { Correlation } \\
\text { coefficient }\end{array}$ & $\begin{array}{c}\text { Sig. } \\
\text { (2-tailed) }\end{array}$ & $\begin{array}{l}\text { Correlation } \\
\text { coefficient }\end{array}$ & $\begin{array}{l}\text { Sig. } \\
\text { (2-tailed) }\end{array}$ \\
\hline Personally tested quality & 9.14 & -.012 & .818 & $.167^{* *}$ & .002 & .038 & .485 \\
\hline Naturalness & 8.39 & .103 & .055 & $.148^{* *}$ & .006 & .100 & .064 \\
\hline Price & 7.97 & -.024 & .650 & -.046 & .393 & $-.214^{* *}$ & .000 \\
\hline Expiry date & 7.84 & $.231^{* *}$ & .000 & -.005 & .928 & $-.114^{*}$ & .035 \\
\hline Product ecology & 7.77 & $.131^{*}$ & .014 & .093 & .084 & .083 & .126 \\
\hline Doctor's recommendations & 7.59 & .071 & .190 & -.072 & .178 & -.074 & .169 \\
\hline Offered discount & 7.54 & .045 & .410 & -.011 & .838 & $-.146^{* *}$ & .007 \\
\hline
\end{tabular}




\begin{tabular}{|c|c|c|c|c|c|c|c|}
\hline $\begin{array}{l}\text { The number and variety of } \\
\text { vitamins and supplements in } \\
\text { the composition of a product }\end{array}$ & 7.20 & $-.111^{*}$ & .040 & .080 & .136 & -.085 & .118 \\
\hline $\begin{array}{l}\text { Large amount of the active } \\
\text { substance of interest }\end{array}$ & 7.14 & .068 & .210 & $.119^{*}$ & .027 & .016 & .776 \\
\hline Large amount for reasonable & & -.034 & .526 & -.018 & .738 & $-.254^{* *}$ & .000 \\
\hline price & 6.52 & & & & & & \\
\hline $\begin{array}{l}\text { Recommendations of friends } \\
\text { and acquaintances }\end{array}$ & 6.49 & $-.204^{* *}$ & .000 & .056 & .303 & .070 & .202 \\
\hline $\begin{array}{l}\text { Recommendations of a } \\
\text { pharmacist }\end{array}$ & 6.33 & -.047 & .380 & -.058 & .280 & $-.140^{* *}$ & .010 \\
\hline Product's country of origin & 6.60 & .045 & .403 & .045 & .403 & .086 & .114 \\
\hline Well-known brand & 6.14 & .070 & .194 & .074 & .168 & .084 & .121 \\
\hline $\begin{array}{l}\text { How many times per day it is } \\
\text { necessary to apply }\end{array}$ & 6.09 & $.178^{* *}$ & .001 & .054 & .317 & -.029 & .590 \\
\hline $\begin{array}{l}\text { How many capsules per day } \\
\text { it is necessary to apply }\end{array}$ & 6.06 & $.150^{* *}$ & .005 & .049 & .365 & -.030 & .579 \\
\hline $\begin{array}{l}\text { Consumers' comments in the } \\
\text { Internet }\end{array}$ & 5.38 & $-.194^{* *}$ & .000 & -.013 & .808 & .054 & .322 \\
\hline Lithuanian brand & 4.76 & .009 & .873 & -.056 & .297 & $-.127^{*}$ & .019 \\
\hline $\begin{array}{l}\text { Comprehensive presentation } \\
\text { on } \mathrm{TV} \text {, radio or in press }\end{array}$ & 3.92 & .001 & .978 & -.036 & .513 & -.053 & .335 \\
\hline Advertising & 3.60 & $-.110^{*}$ & .041 & -.031 & .567 & -.075 & .169 \\
\hline Attractive packaging & 3.15 & $-.298^{* *}$ & .000 & -.048 & .374 & .002 & .964 \\
\hline
\end{tabular}

* 1-not important factor, 10-most important factor while making purchase decisions.

The correlation analysis has disclosed the statistically reliable negative relations between the importance of the large amount for the reasonable price and the income $(\mathrm{r}=-0.254)$; the importance of the recommendations of friends, acquaintances and respondents' age $(\mathrm{r}=-0.204)$; the importance of pharmacist's recommendations and respondents' age $(\mathrm{r}=-0.140)$; the importance of consumers' comments in the Internet and respondents' age $(\mathrm{r}=-0.194)$. the statistically reliable positive relations have been identified between the importance how many times per day and how many capsules of supplements it is necessary to take per day and respondents' age (respectively $\mathrm{r}=0.178 ; 0.150$ ).

The least important factors in the decision making to purchase dietary supplements for the respondents are the following: Lithuanian brand (4.76), comprehensive presentation on TV, radio or in press (3.92), advertising (3.60) and attractive packaging (3.15).

The research results show the statistically significant negative correlation between the importance of Lithuanian brand and respondents' income ( $\mathrm{r}=-0.127)$; the importance of advertising as well as attractive packaging and respondents' age (respectively $\mathrm{r}=-0.110$ and -0.298 ).

The survey results show that, in choosing dietary supplements, the information about the country of origin on the package is always searched by 33.4 percent of the respondents, often this information is searched for by 25.4 percent of the respondents. The information about the producer on the packaging is always searched by 36.8 percent, often -28.3 percent of the respondents. The respondents more often search for the information directly related to the usage of the supplements. The information about the preparation's usage is always read by 70.1 percent of the respondents, their indications -82.4 percent, the instruction for the usage -71.5 percent, the possible side effect -56.7 percent of the respondents. The brand name on the package is always searched by 50.6 percent of the respondents. 


\subsection{Perceptions of Vitamins and Dietary Supplements Produced in Lithuania and Foreign Countries}

\subsubsection{Perceptions of Product Quality}

The research results (Table 3) show that the respondents rate the quality of the dietary supplements produced in Germany and Switzerland (mean 6.16 and 6.13) the highest. The quality of the dietary supplements produced in other surveyed developed countries is high rated as well: Scandinavian countries-mean 5.99; USA-5.88; France-5.79; Japan-5.70; UK-5.43; Belgium-5.22; the Netherlands-5.18. The respondents also rate similarly the quality of the vitamins and dietary supplements produced in Lithuania-5.48.

Lower evaluations of the respondents (however, higher than moderate) were given to the quality of the vitamins and dietary supplements produced in Slovenia and Russia (respectively 4.97 and 4.91). The respondents moderately rate the quality of the vitamins and dietary supplements produced in India (4.17), Poland (4.17), the Ukraine (3.91), and China (3.61).

Table 3. Perceptions on the quality of the vitamins and dietary supplements produced in different countries

\begin{tabular}{lccccccc}
\hline \multirow{2}{*}{ Vitamins and dietary } & Mean* & \multicolumn{3}{c}{ Age } & \multicolumn{2}{c}{ Education } & \multicolumn{2}{c}{ Income } \\
\cline { 3 - 8 } supplements made in & & Correlation & Sig. & Correlation & Sig. & Correlation & Sig. \\
& & coefficient & (2-tailed) & coefficient & (2-tailed) & coefficient & $(2$-tailed) \\
\hline Germany & 6.16 & .092 & .206 & $.282^{* *}$ & .000 & .127 & .083 \\
Switzerland & 6.13 & .149 & .081 & $.344^{* *}$ & .000 & .048 & .584 \\
Scandinavian countries & 5.99 & -.035 & .664 & $.198^{*}$ & .013 & .053 & .508 \\
USA & 5.88 & $.159^{*}$ & .037 & $.216^{* *}$ & .004 & $.170^{*}$ & .026 \\
France & 5.79 & .056 & .574 & $.259^{* *}$ & .008 & -.053 & .589 \\
Japan & 5.70 & $.268^{*}$ & .012 & $.358^{* *}$ & .001 & .208 & .056 \\
Lithuania & 5.48 & $.164^{*}$ & .012 & $.246^{* *}$ & .000 & -.043 & .512 \\
Great Britain & 5.43 & .113 & .187 & $.248^{* *}$ & .003 & .114 & .187 \\
Belgium & 5.22 & -.007 & .949 & $.271^{*}$ & .019 & -.017 & .886 \\
Netherlands & 5.18 & .041 & .744 & $.297^{*}$ & .017 & .064 & .615 \\
Slovenia & 4.97 & $.288^{* *}$ & .004 & $.327^{* *}$ & .001 & .058 & .570 \\
Russia & 4.91 & .084 & .278 & .114 & .141 & $-.189^{*}$ & .014 \\
India & 4.17 & .116 & .307 & .133 & .244 & -.136 & .234 \\
Poland & 4.17 & .146 & .121 & $.213^{*}$ & .023 & -.119 & .207 \\
Ukraine & 3.91 & .109 & .317 & .144 & .182 & $-.226^{*}$ & .034 \\
China & 3.61 & .138 & .194 & .178 & .094 & -.098 & .359 \\
\hline
\end{tabular}

* 1-very low quality, 7-very high quality.

The correlation analysis shows statistically reliable positive relations among the respondents' age, education, income and the evaluation of quality of vitamins dietary supplements made in the USA $(\mathrm{r}=0.159 ; 0.216$ and 0.170 ). During the research the statistically significant positive correlation relation was identified among the respondents' age, education and the evaluations of the quality of the dietary supplements made in Japan ( $\mathrm{r}=0.268$ and 0.358$)$, Lithuania ( $\mathrm{r}=0.164$ and 0.246$)$ and Slovenia ( $\mathrm{r}=0.288$ and 0.327$)$. The statistically reliable negative relation was determined among the respondents' income and the perceived quality of the supplements made in Russia ( $\mathrm{r}=0.189)$ and the Ukraine $(\mathrm{r}=-0.226)$.

\subsubsection{Perceptions of Product Price}

When analyzing the respondents' opinion on the prices of the dietary supplements made in different countries (Table 4), the tendency that the higher the quality of the vitamins and dietary supplements produced in the country is rated, the higher their price, according to the respondents.

According to the respondents, the highest prices are characteristic for the vitamins and dietary supplements produced in developed countries: Switzerland (5.72), Germany (5.51), Japan (5.46), Scandinavian countries 
(5.40), France (5.38), the USA (5.35), UK (5.15), Belgium (5.08), and the Netherlands (5.02). The prices of the vitamins and dietary supplements produced in Lithuania are evaluated a bit higher than moderately (4.66), and moderately-in Slovenia (4.26), India (3.86), Poland (3.65) and China (3.62). According to the respondents, the countries producing the cheapest vitamins and dietary supplements are Russia (3.30) and the Ukraine (3.35). The prices of the vitamins and dietary supplements produced in these countries are lower than moderate, according to the respondents.

Table 4. Perceptions about the price of the vitamins and dietary supplements produced in different countries

\begin{tabular}{|c|c|c|c|c|c|c|c|}
\hline \multirow{2}{*}{$\begin{array}{l}\text { Vitamins and dietary } \\
\text { supplements made in }\end{array}$} & \multirow{2}{*}{ Mean* } & \multicolumn{2}{|c|}{ Age } & \multicolumn{2}{|c|}{ Education } & \multicolumn{2}{|c|}{ Income } \\
\hline & & $\begin{array}{l}\text { Correlation } \\
\text { coefficient }\end{array}$ & $\begin{array}{c}\text { Sig. } \\
\text { (2-tailed) }\end{array}$ & $\begin{array}{l}\text { Correlation } \\
\text { coefficient }\end{array}$ & $\begin{array}{c}\text { Sig. } \\
\text { (2-tailed) }\end{array}$ & $\begin{array}{l}\text { Correlation } \\
\text { coefficient }\end{array}$ & $\begin{array}{c}\text { Sig. } \\
\text { (2-tailed) }\end{array}$ \\
\hline Germany & 5.51 & .118 & .155 & .101 & .223 & -.058 & .488 \\
\hline Switzerland & 5.72 & $.197^{*}$ & .039 & .155 & .104 & .038 & .694 \\
\hline Scandinavian countries & 5.40 & .142 & .117 & $.322^{* *}$ & .000 & .035 & .696 \\
\hline USA & 5,35 & ,139 & ,089 &, 021 & ,793 &,- 124 &, 131 \\
\hline France & 5.38 & $.280^{*}$ & .012 & .171 & .128 & .184 & .105 \\
\hline Japan & 5.46 & .152 & .254 & $.364^{* *}$ & .005 & .115 & .390 \\
\hline Lithuania & 4.66 & -.033 & .634 & .038 & .587 & -.130 & .065 \\
\hline Great Britain & 5.15 & $.262^{* *}$ & .004 & .122 & .180 & .127 & .163 \\
\hline Belgium & 5.08 & $.279^{*}$ & .034 & $.290^{*}$ & .026 & -.052 & .694 \\
\hline Netherlands & 5.02 & .262 & .072 & .194 & .188 & -.069 & .639 \\
\hline Slovenia & 4.26 & .137 & .223 & .199 & .074 & -.103 & .356 \\
\hline Russia & 3.30 & -.049 & .537 & -.003 & .969 & -.112 & .160 \\
\hline India & 3.86 & .162 & .229 & -.162 & .228 & $-.411^{* *}$ & .002 \\
\hline Poland & 3.65 & -.072 & .484 & .018 & .858 & -.193 & .057 \\
\hline Ukraine & 3.35 & .075 & .518 & -.195 & .091 & $-.227^{*}$ & .049 \\
\hline China & 3.62 & $.348^{* *}$ & .004 & .104 & .401 & $-.279^{*}$ & .022 \\
\hline
\end{tabular}

* 1-very low prices, 7 -very high prices.

When analyzing the research data, the statistically significant positive correlation between the respondents' age and the prices of the vitamins and dietary supplements produced in Switzerland ( $\mathrm{r}=0.197)$, France $(\mathrm{r}=0.280)$, UK $(\mathrm{r}=0.262)$, Belgium $(\mathrm{r}=0.279)$, China $(\mathrm{r}=0.348)$ have been identified. Statistically significant positive correlation have been identified between the respondents' education and the evaluations of the prices of the vitamins and dietary supplements produced in Scandinavian countries ( $\mathrm{r}=0.155)$, Japan $(\mathrm{r}=0.364)$ and Belgium $(\mathrm{r}=0.290)$. The negative correlation was found between the respondents' income and the evaluation of the prices of the vitamins and dietary supplements produced in India $(\mathrm{r}=-0.411)$, the Ukraine $(\mathrm{r}=-0.227)$ and China $(\mathrm{r}=-0.279)$.

\subsubsection{Perceptions of Product Safety}

The data on the respondents' perceptions on the safety of the vitamins and dietary supplements produced in different countries are presented in Table 5. According to the respondents, the most secure vitamins and dietary supplements are produced in developed countries: Switzerland (2.94), Germany (2.93), Scandinavian countries (2.87), France (2.86), UK (2.85), the Netherlands (2.78), Belgium (2.76), and Japan (2.74). The respondents attribute the vitamins and dietary supplements produced in Lithuania (2.72) to this group.

The respondents are subject to doubt about the safety on the vitamins and dietary supplements produced in Slovenia (2.49) and the neighboring countries-Poland (2.14), Russia (2.13). The safety of the vitamins and dietary supplements produced in China (1.56), India (1.72) and the Ukraine (1.93) are evaluated the worst.

The analysis revealed the statistically reliable negative correlation between the respondents' age and the perceived safety of the vitamins and dietary supplements produced in Scandinavian countries $(\mathrm{r}=-0.230)$. 
Positive correlation has been identified between the respondents' education and the perceived safety of the vitamins and dietary supplements produced in Lithuania and Poland $(\mathrm{r}=0.143$ and 0.236$)$. Table 5 shows that the vitamins and dietary supplements produced in Scandinavian countries, the USA, France, and Belgium are perceived as more secure as the respondents' income increase (correlation coefficients are 0.199; 0.160; 0.194; 0.186 respectively).

Table 5. Perceptions on the safety of the vitamins and dietary supplements produced in different countries

\begin{tabular}{|c|c|c|c|c|c|c|c|}
\hline \multirow{2}{*}{$\begin{array}{l}\text { Vitamins and dietary } \\
\text { supplements made in }\end{array}$} & \multirow{2}{*}{ Mean* } & \multicolumn{2}{|c|}{ Age } & \multicolumn{2}{|c|}{ Education } & \multicolumn{2}{|c|}{ Income } \\
\hline & & $\begin{array}{l}\text { Correlation } \\
\text { coefficient }\end{array}$ & $\begin{array}{c}\text { Sig. } \\
\text { (2-tailed) }\end{array}$ & $\begin{array}{l}\text { Correlation } \\
\text { coefficient }\end{array}$ & $\begin{array}{c}\text { Sig. } \\
\text { (2-tailed) }\end{array}$ & $\begin{array}{l}\text { Correlation } \\
\text { coefficient }\end{array}$ & $\begin{array}{c}\text { Sig. } \\
\text { (2-tailed) }\end{array}$ \\
\hline Germany & 2.93 & -.089 & .232 & -.015 & .840 & .014 & .853 \\
\hline Switzerland & 2.94 & -.076 & .353 & .078 & .338 & .090 & .268 \\
\hline Scandinavian countries & 2.87 & $-.230^{* *}$ & .004 & .077 & .344 & $.199^{*}$ & .014 \\
\hline USA & 2,75 & -.024 & .742 & .051 & .493 & $.160^{*}$ & .031 \\
\hline France & 2.86 & -.150 & .087 & .083 & .343 & $.194^{*}$ & .026 \\
\hline Japan & 2.74 & .065 & .484 & .145 & .118 & .085 & .360 \\
\hline Lithuania & 2.72 & .112 & .095 & $.143^{*}$ & .034 & -.056 & .406 \\
\hline Great Britain & 2.85 & -.011 & .891 & .057 & .475 & -.027 & .736 \\
\hline Belgium & 2.76 & -.054 & .568 & .141 & .135 & $.186^{*}$ & .047 \\
\hline Netherlands & 2.78 & -.136 & .165 & .064 & .516 & .104 & .294 \\
\hline Slovenia & 2.49 & .037 & .684 & .103 & .258 & -.048 & .603 \\
\hline Russia & 2.13 & .109 & .133 & .039 & .596 & -.002 & .981 \\
\hline India & 1.72 & .015 & .869 & .041 & .653 & .037 & .689 \\
\hline Poland & 2.14 & .062 & .453 & $.236^{* *}$ & .004 & .101 & .219 \\
\hline Ukraine & 1.93 & .002 & .986 & -.045 & .612 & .032 & .724 \\
\hline China & 1.56 & -.057 & .505 & -.100 & .244 & -.002 & .984 \\
\hline
\end{tabular}

* 1-not safe to use a product, 2-doubt about a product safety, 3-confident about a product safety.

\subsubsection{Perceptions of Dietary Supplements Produced in Economics of Different Development Level}

Table 6 presents the data that enable to deeper understand the reasons why the respondents more trust the vitamins and dietary supplements produced in developed countries.

The respondents more agree to the statements that developed countries have larger experience in producing vitamins and dietary supplements; thus they can ensure better quality of vitamins and dietary supplements (4.59); these countries can allocate more funds for research, thus they can offer better-quality vitamins and dietary supplements (4.56). The data show that the respondents are subject not to agree that the quality of produced vitamins and dietary supplements is controlled alike in all countries (2.98).

The research results show that for the respondents it is more important than unimportant that the vitamins and dietary supplements they and their relatives use would be produced in developed countries. This attitude gets stronger with getting older. 
Table 6. Opinions about the vitamins and dietary supplements produced in economies of different development

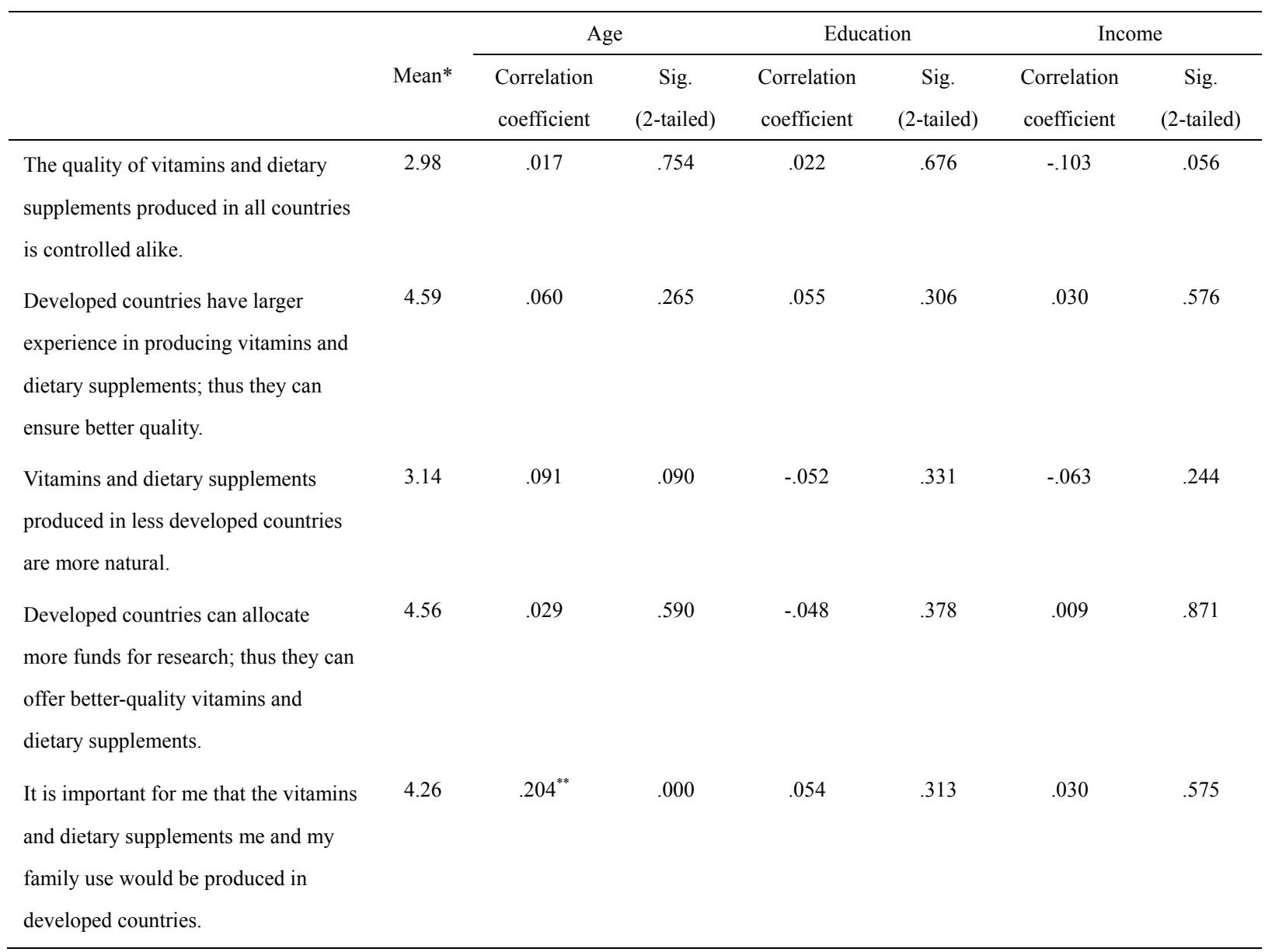

*1-strongly disagree, 6-strongly agree.

\section{Hypotheses Testing and Study Results Discussion}

\section{$5.1 \mathrm{H1}$}

It was hypothesized in $\mathrm{H} 1$ that, when making decisions for purchasing vitamins and dietary supplements, the country of origin is more important for a consumer than supplements' brandname. Referring to the above-presented data, $\mathrm{HI}$ is denied. The data collected during the survey show that the country of origin of vitamins and dietary supplements is as important (mean 6.16) as the product's brandname (6.14). Both named factors are attributed to the group of factors of moderate importance.

\section{$5.2 \mathrm{H} 2$}

The research data (Fig. 1 and Fig. 2) show that the respondents the mostly highly rate the quality and safety of the vitamin and dietary supplements produced in developed economies (Switzerland, Germany, the USA, Japan, France, Great Britain, Belgium, and the Netherlands). The price of the vitamins and dietary supplements produced in these countries is perceived as high or very high.

It should be noted that the consumers relate the vitamins and dietary supplements produced in Lithuania to high quality of services and to higher than moderate price. According to the respondents, the quality and price of the vitamins and dietary supplements produced in Lithuania is closer to the quality and price of the vitamins and dietary supplements produced developed countries than to the quality and price of the vitamins and dietary supplements produced in Slovenia or the neighboring countries. 


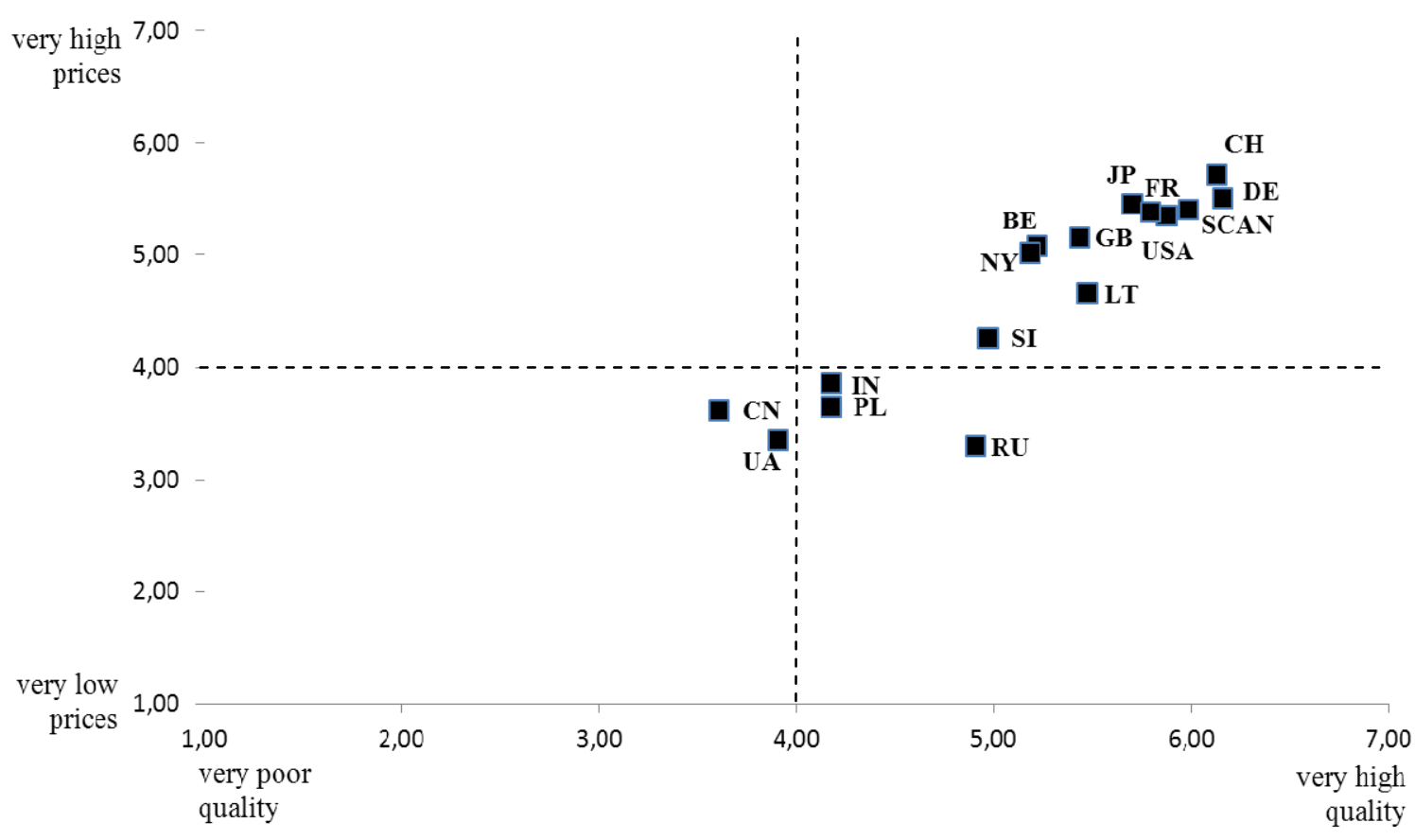

Figure 1. Perceptions on the quality and price of the vitamins and dietary supplements produced in Lithuania and foreign countries

Note: UA-Ukraine, CN-China, IN-India, PL-Poland, RU-Russia, SI-Slovenia, LT-Lithuania, NY-Netherlands, BE-Belgium, GB-Great Britain,

USA-United States of America, JP-Japan, FR-France, SCAN- Scandinavian countries, DE-Germany, CH-Switzerland.

Figure 2 shows that the vitamins and dietary supplements produced in Lithuania as well as in the surveyed developed countries are associated with safety. That is the respondents think that such supplements are secure to use. The vitamins and dietary supplements produced in Slovenia falls on the margin among the countries producing the high quality supplements secure to use and high quality but among the ones raising doubts.

The consumers associate the vitamins and dietary supplements produced in the neighboring countries of Lithuania-Poland and Russia - with the higher than moderate quality and lower than moderate price. The vitamins and dietary supplements produced in the Ukraine and Chine are perceived as the products of lower than moderate price and lower than moderate quality.

Referring to these data, hypothesis $\mathrm{H} 2 \mathrm{a}$ is supported partly. The respondents highly rated not only the vitamins and dietary supplements produced in developed countries but also the quality and safety of the supplements produced in the local economics.

Hypothesis $\mathrm{H} 2 \mathrm{~b}$ is supported partly. The respondents rated the vitamins and dietary supplements produced in China, the Ukraine, Poland, India and Russia the worst; however, the vitamins and dietary supplements produced in Lithuania got the same good evaluations as the vitamins and supplements produced in developed economies.

\section{$5.3 \mathrm{H3}$}

In H3, it was hypothesized that the Lithuanian consumers rate the Lithuanian vitamins and dietary supplements similarly as the vitamins and dietary supplements produced in the neighboring countries-Russia, Poland, but worse than the vitamins and supplements produced in developed economies.

Referring to the data obtained during the research (Fig. 1 and 2), hypothesis H3 is denied. The respondents rated the dietary supplements produced in Lithuania similarly as the dietary supplements produced in developed economies and much higher than the supplements produced in the neighboring countries-Russia and Poland. 


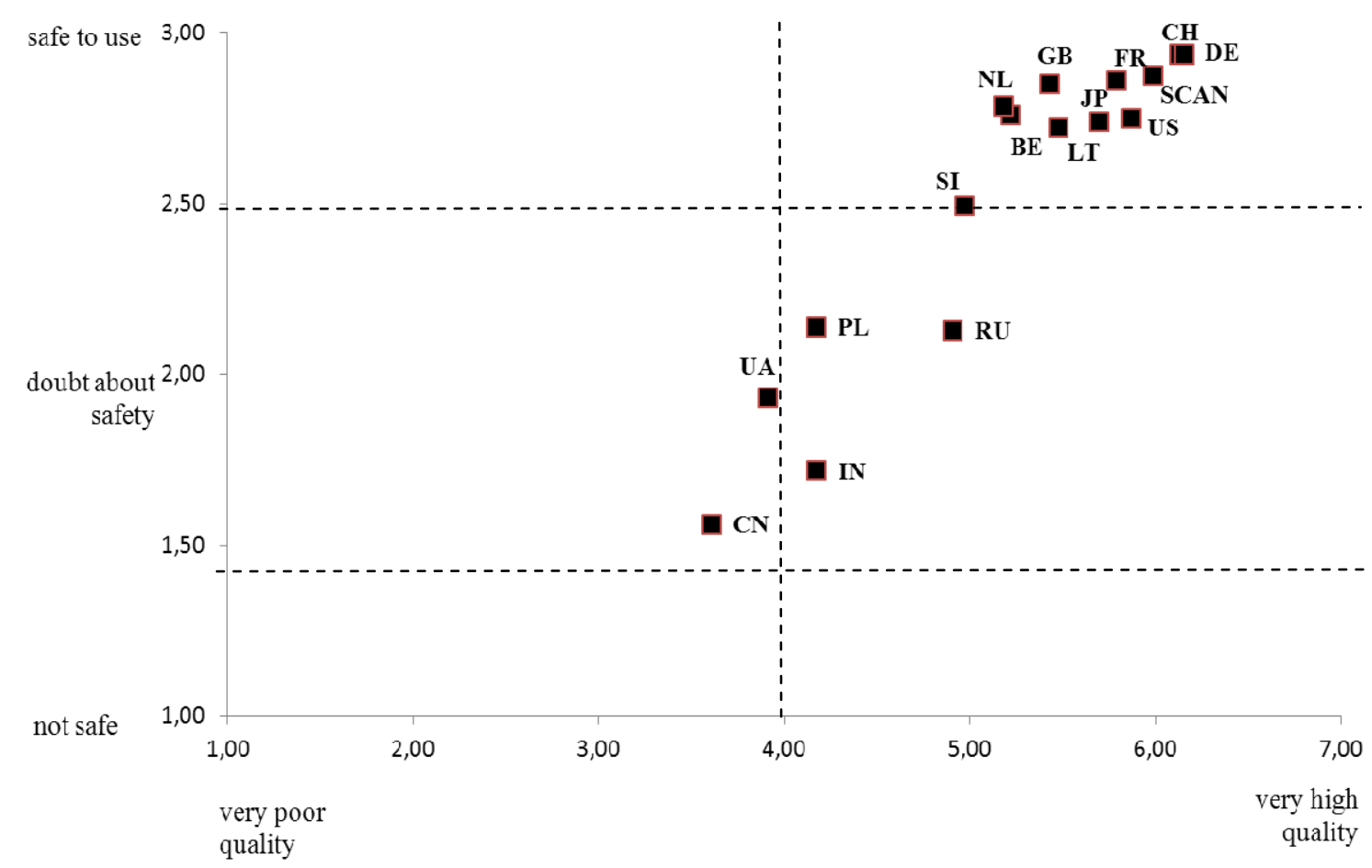

Figure 2. Respondents' perceptions on the quality and safety of the vitamins and dietary supplements produced in Lithuania and foreign countries

Note: UA-Ukraine, CN-China, IN-India, PL-Poland, RU-Russia, SI-Slovenia, LT-Lithuania, NY-Netherlands, BE-Belgium, GB-Great Britain, USA-United States of America, JP-Japan, FR-France, SCAN- Scandinavian countries, DE-Germany, CH-Switzerland.

\section{$5.4 H 4 a, H 4 b$, and $H 4 c$}

It was hypothesized in H4a that consumers with lower level of education have more favourable perceptions of Lithuanian vitamins and dietary supplements.

The performed correlation analysis show the statistically reliable positive relations between the respondents' education and quality evaluation of the vitamins and dietary supplements produced both in developed countries and in Lithuania (Germany $r=0.282$; Switzerland $r=0.344$; Scandinavian countries $r=0.198$; the USA $r=0.216$; France $r=0.259$; Japan $r=0.358$; Lithuania $r=0.246$; Great Britain $r=0.248$; Belgium $r=0.271$; the Netherlands $\mathrm{r}=0.297$; Poland $\mathrm{r}=0.213$ ). That is, the higher consumers' education, the more favorably they evaluate the quality of the vitamins and supplements produced in Lithuania.

Having performed the correlation analysis of the respondents' education and their opinion about the safety of the vitamins and dietary supplements produced in Lithuania, the statistically reliable positive relation between the education and safety of the Lithuanian vitamins and dietary supplements perceived by the respondents has been identified ( $\mathrm{r}=0.143$ ). Referring to these data, H4a is denied.

In $\mathrm{H} 4 \mathrm{~b}$, it was hypothesized that older consumers have more favourable perceptions of vitamins and dietary supplements produced in Lithuania and neighboring countries.

Having performed the correlation analysis of the respondents' age and the evaluations on the quality of the vitamins and dietary supplements produced in Lithuania, Poland, Russia and the Ukraine (countries related to Lithuania in historical relations), the statistically reliable positive relation between the age and the perceived quality of the vitamins and dietary supplements produced in Lithuania $(\mathrm{r}=0.164)$ has been identified. Other statistically reliable relations have not been identified.

Reliable relations between the perceived safety of the vitamins and dietary supplements produced in Lithuania, Poland, Russia and the Ukraine and the age have not been identified during the research. Reliable relations between the perceived price of the supplements produced in Lithuania, Poland, Russia and the Ukraine and the 
age have not be found. Referring to these data, $H 4 b$ is denied.

In $\mathrm{H} 4 \mathrm{c}$, it was hypothesized that consumers with low income have more favourable perceptions of the vitamins and dietary supplements produced in Lithuania and neighboring countries.

The performed correlation analysis between the respondents' income and the perceptions on the quality of the vitamins and dietary supplements produced in Lithuania, Poland, Russia, the Ukraine shows the statistically reliable negative relations between the respondents' income and the perceptions on the quality of the supplements produced in Russia ( $\mathrm{r}=-0.189)$, the Ukraine $(\mathrm{r}=-0.226)$.

The correlation analysis of the respondents' income and the perception of the price of the vitamins and supplements produced in the Ukraine show the statistically reliable negative relation $(\mathrm{r}=-0.227)$. The correlation analysis of the respondents' income and their perceptions on the safety of the supplements produced in Lithuania, Poland, Russia and the Ukraine has not shown the statistically reliable relations. Referring to these data, $\mathrm{H} 4 \mathrm{c}$ is partly supported.

\section{Conclusions}

The study provides a comprehensive picture of a country of origin effect in a Lithuanian market of vitamins and dietary supplements. The research results reveal the respondents' perceptions on the vitamins and dietary supplements produced in Lithuania and fifteen foreign countries, and it is also shows how important the vitamins and dietary supplements' country of origin is for consumers when making purchase decisions.

The results of the research on the country-of-origin effect in the Lithuanian market of vitamins and dietary supplements verify the theoretical approach that the products produced in developed economies are perceived as the ones of better quality. The vitamins and dietary supplements produced in Germany, Switzerland, the USA, France, Japan, Scandinavian countries are rated as the vitamins and dietary supplements of the highest quality. The vitamins and dietary supplements produced in the local economy, despite its lower development level, are also rated high as the vitamins and dietary supplements produced in developed countries.

The customers' perceptions on prices and safety of the products produced in Lithuania and foreign countries, which have been surveyed during the research, show that these factors are also perceived as analogous for the quality. That is the prices of vitamins and dietary supplements produced in developed economies are perceived as much higher than the prices of the supplements produced in less developed economies. The consumers are more secure towards the safety of the dietary supplements produced in developed countries and are subject to doubt about the safety of the dietary supplements produced in the lower development economy. The prices and safety of the vitamins and dietary supplements produced in the local economy are similarly recognized as the perceived price and safety of the vitamins and dietary supplements produced in developed countries. That is the consumers are secure for product's safety, and the perceived level of prices is close to the prices of the vitamins and dietary supplements produced in developed countries.

Despite the clear perceptions of the consumers about the vitamins and dietary supplements produced in different countries, the study results indicate that the product's country of origin is the factor of moderate importance. When a Lithuanian consumer of vitamins and dietary supplements makes decisions to purchase, for him / her the personally tried product's quality, naturalness of the vitamins and dietary supplements, their price and offered discounts, doctor's recommendations and product ecology are much more important.

During the research the hypothesis that the consumers possessing lower education more favorably rate the vitamins and dietary supplements produced in Lithuania has been denied. The hypothesis that older consumers more favorably rate the vitamins and dietary supplements produced in Lithuania and neighboring countries has also been denied. The hypothesis that the consumers getting low income more favorably rate the vitamins and dietary supplements produced in Lithuania and neighboring countries has been partly verified.

The research results indicate that Lithuanian consumers of vitamins and dietary supplements rate the supplements produced in Russia and Poland (i.e., in the countries having cultural, historic and economic similarities) much worse than the supplements produced in the local market and developed countries. Such research results indicate one of the possible future research directions - to perform deeper analysis of Lithuanian consumers' animosity towards neighboring countries and the products they produce.

\section{References}

Agrawal, J., \& Kamakura, W. A. (1999). Country of origin: a competitive advantage? International Journal of Research in Marketing, 16, 255-267. http://dx.doi.org/10.1016/S0167-8116(99)00017-8

Ahmed, S. A., \& d'Astous, A. (2008). Antecedents, moderators and dimensions of country-of-origin evaluations. 
International Marketing Review, 25(1), 75-106. http://dx.doi.org/10.1108/02651330810851890

Bloemer, J., Brijs, K., \& Kasper, H. (2009). The COO-ELM model: A theoretical framework for the cognitive processes underlying country of origin-effects. European Journal of Marketing, 43(1/2), 62-89. http://dx.doi.org/10.1108/03090560910923247

Chattalas, M., Kramer, T., \& Takada, H. (2008). The impact of national stereotypes on the country of origin effect: A conceptual framework. International Marketing Review, 25(1), 54-74. http://dx.doi.org/10.1108/02651330810851881

Chu, P. Y., Chang, Ch., Chen, Ch., \& Wang, T. W. (2010). Countering negative country-of-origin effects: The role of evaluation mode. European Journal of Marketing, 44(7/8), 1055-1076. http://dx.doi.org/10.1108/03090561011047526

Clemens, R., \& Babcock, B. A. (2004). Country of Origin as a Brand: The Case of New Zealand Lamb. MATRIC Briefing Paper 04-MBP 9. Retrieved June 15, 2013, from http://www.card.iastate.edu/publications/dbs/pdffiles/04mbp9.pdf

Drozdenko, R., \& Jensen, M. (2009). Translating country-of-origin effects into prices. Journal of Product \& Brand Management, 18(5), 371-378. http://dx.doi.org/10.1108/10610420910981855

Ghazali, M., Othman, S. M., Yahya, A. Z., \& Ibrahim, M. S. (2008). Products and Country of Origin Effects: The Malaysian Consumers' Perception. International Review of Business Research Papers, 4(2), 91-102.

Hong, S. T., \& Kang, D. K. (2006). Country-of-origin Influences on product Evaluations: The Impact of Animosity and Perceptions of Industriousness Brutality on Judgments of Typical and Atypical Products. Journal of Consumer Psychology, 16(3), 232-239. http://dx.doi.org/10.1207/s15327663jcp1603_5

Insch, A., \& Florek, M. (2009). Prevalence of country of origin associations on the supermarket shelf. International Journal of Retail \& Distribution Management, 37(5), 453-471. http://dx.doi.org/10.1108/09590550910954937

Ittersuma, K., Candelb, M. J. J. M., \& Meulenberga, M. T. G. (2003). The influence of the image of a product's region of origin on product evaluation. Journal of Business Research, 56, 215-226. http://dx.doi.org/10.1016/S0148-2963(01)00223-5

Jeong, S. W., Stoel, L., \& Chung, J. E. (2012). Impacts of store type importance and country of origin: Exploring the case of dietary supplements in the Chinese market. International Journal of Retail \& Distribution Management, 40(6), 471-87. http://dx.doi.org/10.1108/09590551211230278

Josiassen, A., \& Assaf, A. (2010). Country-of-origin contingencies: their joint influence on consumer behavior. Asia Pacific Journal of Marketing and Logistics, 22(3), 294-313. http://dx.doi.org/10.1108/13555851011062241

Kaynak, E., Kucukemiroglu, O., \& Hyder, A. S. (2000). Consumers' country-of-origin (COO) perceptions of imported products in a homogenous less-developed country. European Journal of Marketing, 34(9/10), 1221-1241. http://dx.doi.org/10.1108/03090560010342610

Li, X., Yang, J., Wang, X., \& Lei, D. (2012). The impact of country-of-origin image, consumer ethnocentrism and animosity on purchase intention. Journal of Software, 7(10), 2263-2268. http://dx.doi.org/10.4304/jsw.7.10.2263-2268

Magnusson, P., Westjohn, S. A., \& Zdravkovic, S. (2011). "What? I thought Samsung was Japanese": accurate or not, perceived country of origin matters. International Marketing Review, 28(5), 454-472. http://dx.doi.org/10.1108/02651331111167589

Mockaitis, A. I., Salciuviene, L., \& Ghauri, P. N. (2013). On What Do Consumer Product Preferences Depend? Determining Domestic versus Foreign Product Preferences in an Emerging Economy Market. Journal of International Consumer Marketing, 25(3), 166-180. http://dx.doi.org/10.1080/08961530.2013.780456

Nijssen, E. J., \& Douglas, S. P. (2004). Examining the animosity model in a country with a high level of foreign trade. International Journal of Research in Marketing, 21, 23-38. http://dx.doi.org/10.1016/j.jiresmar.2003.05.001

Vitamins and dietary supplements in Lithuania. Euromonitor International. (2013). Retrieved June 15, 2013, from http://www.portal.euromonitor.com

Phau, I., \& Suntornnond, V. (2006). Dimensions of consumer knowledge and its impact on country of origin 
effects among Australian consumers: a case of fast-consuming product. Journal of Consumer Marketing, 31(1), 34-42. http://dx.doi.org/10.1108/07363760610641145

Profeta, A. (2008). A Theoretical Framework for Country-of-Origin-Research in the Food sector. MPRA Paper No. 20540. Discussion Paper 01-2008. Retrieved March 15, 2013, from http://mpra.ub.uni-muenchen.de/20540

Rezvani, S., Shenyari, G., \& Dehkordi, G. J. (2012). Country of Origin: A Study over Perspective of Intrinsic and Extrinsic Cues on Consumers' Purchase Decision. Business Management Dynamics, 1(11), 68-75.

Russell, D. W., \& Russell, C. A. (2006). Explicit and implicit catalysts of consumer resistance: the effects of animosity, cultural salience and country-of-origin on subsequent choice. International Journal of Research in Marketing, 23(3), 321-331. http://dx.doi.org/10.1016/j.ijresmar.2006.05.003

Samli, A. C. (2013). International Consumer Behavior in the $21^{\text {st }}$ Century. New York: Springer Science \& BusinessMedia.

Sanyal, S. N., \& Datta, S. K. (2011). The effect of country of origin on brand equity: an empirical study on generic drugs. Journal of Product \& Brand Management, 20(2), 130-140. http://dx.doi.org/10.1108/10610421111121125

Schweiger, G., Otter, T., \& Strebinger, A. (1997). The influence of country of origin and brand on product evaluation and the implication thereof for location decisions. Retrieved June 15, 2013, from http://www.wu.ac.at/werbung/download/publikationen/97cems.pdf

Tseng, T. H., \& Balabanis, G. (2011). Explaining the product-specificity of country-of-origin effects. International Marketing Review, 28(6), 581-600. http://dx.doi.org/10.1108/02651331111181420

Urbonavicius, S., Dikcius, V., \& Navickaite, S. (2011). Country Image and Product Evaluations: Impact of a Personal Contact with a Country. Inzinerine Ekonomika-Engineering Economics, 22(2), 214-221. http://dx.doi.org/10.5755/j01.ee.22.2.318

Urbonavicius, S., \& Gineikiene, J. (2009). Importance of the product country-of-origin factor on purchasing process in the context of glabalisation. Ekonomika, 85, 37-44.

Usunier, J. C. (2006). Relevance in business research: the case of country-of-origin research in marketing. European Management Review, 3(2), 60-73. http://dx.doi.org/10.1057/palgrave.emr.1500049

Verlegh, P. W. J. (2007). Home country bias in product evaluation: The complementary roles of economic and socio-psychological motives. Journal of International Business Studies, 38, 361-373. http://dx.doi.org/10.1057/palgrave.jibs.8400269

Verlegh, P. W. J., Stennkamp, J. B. E. M., \& Meulenberg, T. G. (2005). Country-of-origin effects in consumer processing of advertising claims. International Journal of Research in Marketing, 22, 127-139. http://dx.doi.org/10.1016/j.ijresmar.2004.05.2003

Wang, C. L., Li, D., Barnes, B. R., \& Ahn, J. (2012). Country mage, product image and consumer purchase intention: evidence from an emerging economy. International Business Review, 21, 1041-1051. http://dx.doi.org/10.1016/j.ibusrev.2011.11.010

Zhang, Y. (1996). Chinese consumers' evaluation of foreign product: the influence of culture, product types and product presentation format. European Journal of Marketing, 30(12), 50-68. http://dx.doi.org/10.1108/03090569610153309

\section{Copyrights}

Copyright for this article is retained by the author(s), with first publication rights granted to the journal.

This is an open-access article distributed under the terms and conditions of the Creative Commons Attribution license (http://creativecommons.org/licenses/by/3.0/). 